\title{
UWAGI O PATRologiI W POLSCE
}

Jeśli mówimy o dzisiejszym stanie patrologii w Polsce, dobrze jest rzucić okiem w przeszłość. W XIX wieku ukazywały się u nas tu i ówdzie przekłady pism Ojców Kościoła używane przeważnie w kaznodziejstwie, stąd drukowała je stosunkowo często „Homiletyka” włocławska, a patrologię łączono przeważnie $\mathrm{z}$ homiletyką. Badań $w$ tej dziedzinie nie prowadzono. Wyjątkiem jest tu kilka dobrych prac pisanych przez Polaków na uniwersytetach niemieckich, np. dotąd powszechnie cytowane prace B. Czapli (1872-1926) o Gennadiuszu ${ }^{1}$ czy G. von Dialowskiego o Izydorze $z$ Sewilli ${ }^{2}$. Po tych dobrych doktoratach ich autorzy nikną ze sceny naukowej, wsiąkłszy prawdopodobnie bezpowrotnie w duszpasterstwo. Dwaj świetnie zapowiadający się uczeni: J. Bilczewski (1860-1923) ${ }^{3}$ i A. Lisiecki (1880-1930) ${ }^{4}$ zostali biskupami - lwowskim i katowickim.

W dwudziestoleciu międzywojennym na czterech Wydziałach Teologii była wprawdzie patrologia, ale poza kilkoma niewielkimi pracami, nie powstały wtedy jakieś ważniejsze dzieła. Jedynym naprawdę aktywnym profesorem w dziedzinie patrologii był ks. Jan Czuj, profesor Uniwersytetu Warszawskiego ${ }^{5}$. Seria Pism Ojców Kościoła, prowadzona przez klasyka-bizanty-

${ }^{1}$ Por. B. Czapla, Gennadius als Literarhistoriker (Kirchengeschichtliche Studien 4, 1, hrsg. von Knöpfer), Münster 1898; SPTK V 248-250.

${ }^{2}$ Por. G. von Dialowski, Isidor und Ildefons als Literaturhistoriker, Münster 1898.

${ }^{3}$ Por. W. Urban, Arcybiskup Józef Bilczewski jako archeolog chrześcijański, VoxP 4(1984) z. 6-7, 363-370; SPTK I 157-163.

${ }^{4}$ Por. Cz. Mazur, Ks. Biskup Arkadiusz Lisiecki inicjator serii „Pisma Ojców Kościoła w polskim ttumaczeniu”, "Śląskie Studia Historyczno-Teologiczne” 18(1985) 113-120; jego ważniejsze publikacje: Konstantyn Wielki, Poznań 1913; Czasy Apostolskie, Poznań 1914; Czasy męczeńskie Kościoła Świętego, Poznań 1915; Zasady, metody, technika i plan wydawnictwa „Pisma Ojców Kościoła”, „Przegląd Homiletyczny” 2(1924) 6-23; jego przekłady: Pisma Ojców Apostolskich, POK 1, Poznań 1924; Euzebiusz z Cezarei, Historia kościelna, POK 3, Poznań 1924; Św. Justyn, Apologie - Dialog z Żydem Tryfonem, POK 4, Poznań 1926; SPTK VI 335-338.

${ }^{5}$ Por. W. Kania, Ks. Jan Czuj-wybitny krzewiciel myśli patrystycznej w Polsce, TST 8(1981) 357-364; Cz. Mazur, Materiaty do bibliografii prac ks. Jana Czuja, SACh 2(1980) 236-243; SPTK V 271-273. 
nistę Jana Sajdaka, profesora Uniwersytetu Poznańskiego, człowieka świeckiego, zakończyła się katastrofą ekonomiczną: tomy się nie rozchodziły. Opublikowany w 1936 r. tom XVII dostarcza nam rozwiązania zagadki: serię prenumerowało niewiele ponad 200 osób i instytucji; nawet nie wszystkie Wydziały Teologiczne, a z rzadka tylko seminaria duchowne! Nakład i rękopisy przygotowane do druku zniszczyli Niemcy wchodząc do Poznania. Podobnie katastrofą zakończyła się akcja ks. F. Machaya, który w czasie wojny doprowadził do przełożenia niektórych pism Jana Chryzostoma, Grzegorza z Nazjanzu, Bazylego Wielkiego i Grzegorza z Nyssy przez znakomitego hellenistę prof. Tadeusza Sinkę i zaczął je wydawać po wojnie w założonym przez siebie Wydawnictwie Mariackim ${ }^{6}$ : cztery wydane tomy leżały w Księgarni Krakowskiej do lat sześćdziesiątych, a potem znikły i poszły prawdopodobnie na przemiał. Z tych przekładów J.M. Szymusiak wydał poezje ${ }^{7}$, a Instytut Wydawniczy PAX mowy Grzegorza z Nazjanzu ${ }^{8}$ oraz wybór pism Grzegorza z Nyssy ${ }^{9}$. Reszta leży w krakowskiej Papieskiej Akademii Teologicznej; ukazały się dotąd zaledwie dwa tomy Komentarza do listu do Rzymian Jana Chryzostoma ${ }^{10}$.

Wszystko więc wskazywało na to, że podobnym niepowodzeniem zakończy się również działalność Instytutu Wydawniczego PAX, który od roku 1950 systematycznie publikował także przekłady pism Ojców Kościoła. I te znowu zalegały półki przez całe lata - starsi z nas dobrze to pamiętają. Podobnie rzecz się miała z pierwszymi tomami Pism Starochrześcijańskich Pisarzy, która to seria zaczęła ukazywać się w 1969 r. na ATK pod redakcją jej inicjatora ks. prof. M. Michalskiego; po jego przejściu na emeryturę pałeczkę przejął o. E. Stanula wraz z zespołem redakcyjnym z ATK. W tym samym roku powstał Międzywydziałowy Zakład Antyku Chrześcijańskiego pod kierownictwem o. J.M. Szymusiaka SJ i prof. L. Małunowiczówny, a obok nich nad Klemensem Aleksandryjskim pracowała w Lublinie prof. J. Pliszczyńska. Praca tych trzech zespołów: PAX-u, PSP i Zakładu, zupełnie zresztą niezależnie od siebie, doprowadziła do tego, że w końcu lat siedemdziesiątych nagromadzone na półkach książki patrystyczne zaczęły gwałtownie znikać i od tego czasu dzieje się to regularnie. Książka patrystyczna zdobyła czytelnika! Jest to

${ }^{6}$ W Wydawnictwie Mariackim ukazały się: Św. Bazyli Wielki, Wybór homilij i kazań, Kraków 1947; Sw. Jan Złotousty, Dwadzieścia homilij i mów, Kraków 1947; Św. Jan Złotousty, Homilie na listy pasterskie św. Pawła i na List do Filemona, Kraków 1949.

7 Por. J.M. Szymusiak, Grzegorz Teolog, Poznań 1965, 395-565 (Poezje św. Grzegorza z Nazjanzu - tłum. T. Sinko).

${ }^{8}$ Por. Św. Grzegorz z Nazjanzu, Mowy wybrane, Warszawa 1967.

${ }_{9}$ Por. Św. Grzegorz z Nyssy, Wybór pism, przełożył z greckiego i wyboru dokonał T. Sinko, Warszawa 1963.

${ }^{10}$ Por. Św. Jan Chryzostom, Homilie na List św. Pawta do Rzymian, tłum. T. Sinko, opracowanie tekstu A. Baron, t. I 1-2, Kraków 1995, 1998. 
pierwszy i chyba jeden z największych sukcesów polskich patrologów, sukces, można śmiało powiedzieć - w skali światowej.

Spojrzyjmy więc najpierw na problem tłumaczeń dzieł Ojców Kościoła. Po wojnie wydano w Polsce ok. 200 tomów różnych pism Ojców Kościoła.

Najstarszy ich wydawca Instytut Wydawniczy PAX opublikowal ponad 40 tomów (niestety bez serii) z tak ważnymi dziełami jak: Listy Bazylego, Hieronima i Grzegorza W., Dialogi filozoficzne, O państwie Bożym i Wyznania św. Augustyna, dzieła trzech historyków Kościoła, niektóre dzieła Ambrożego, Jana Damasceńskiego, Grzegorza z Nyssy, pisma o św. Antonim i szereg innych $^{11}$. Do nich dołączył wydanie kilku podstawowych opracowań, jak: Patrologię B. Altanera (bez bibliografii polskiej!), Historię doktryny chrześcijańskiej J.N.P. Kellego, Filozofię średniowieczna E. Gilsona i inne.

Największą polską serią przekładów Ojców Kościoła jest niewątpliwie seria Pisma Starochrześcijańskich Pisarzy (PSP), której bezwzględnie najważniejszym osiągnięciem jest przyswojenie dzieł Orygenesa w przekładzie dra S. Kalinkowskiego. Z innych ważniejszych dzieł warto wymienić pisma Tertuliana, Jana Chryzostoma, listy Cypriana, dzieła Ambrożego, Hieronima, Grzegorza W., Atanazego i Cyryla Aleksandryjskiego, poezje Prudencjusza i inne. Natomiast Augustyn w tej serii wyraźnie nie miał szczęścia ${ }^{12}$. PSP obejmująca 61 tomów jest jedną z ważnych serii przekładów w Europie. Jeżeli jednak ATK zapisała się przez nią złotymi głoskami w historii polskiej teologii, to uczelni tej, na której powstała ta seria, przypadł również bynajmniej nie zaszczytny tytuł jej grabarza. Ale jest to śmierć chwalebna, bo z niej zrodziły się obydwie najbardziej dziś dynamicznie rozwijające się serie Źródła Myśli Teologicznej WAM (15 tomów), tynieckie Źródła Monastyczne (22 tomy), wydawana przez Wydawnictwo M Biblioteka Ojców Kościoła (12 tomów) oraz w pewnym stopniu seria Ojcowie Żywi (Znak, WAM, 16 tomów).

Wolno i systematycznie, około tomu rocznie ukazuje się seria Ojcowie Żywi. Usnęła na III tomie dobrze zapowiadająca się seria antologii KUL-u Starożytne Teksty Chrześcijańskie, choć wiem, że przygotowywany jest do druku IV jej tom poświęcony kapłaństwu wczesnochrześcijańskiemu, podobnie jak Apokryfy Nowego Testamentu, które musiały zmienić wydawcę - przejął je WAM (tom III w druku). Umarł również POK po wydaniu po wojnie zaledwie kilku tomów. Patowska seria Dzieł Jana Chryzostoma już w drugiej części I tomu uciekła się do pomocy wielkiego mecenasa patrystycznego - do WAM-u.

$\mathrm{Z}$ tego co powiedziano widzimy, że w ciągu ostatnich dwudziestu lat zmieniła się zasadniczo sytuacja przekładowa: wszystkie patrystyczne serie przekładów

11 Por. S. Longosz, Polskie wydawnicze serie patrystyczne, w: Sz. Pieszczoch, Patrologia, wyd. 3 (uzupełnione), Gniezno 1998, 169-186, spec. 175-176 (Wydawnictwo PAX).

12 Por. S. Longosz, ,Pisma Starochrześcijańskich Pisarzy” na tle innych polskich serii patrystycznych, w: Dla kogo „Pisma Starochrześcijańskich Pisarzy”. Materiaty z sympozjum patrystycznego, SACh 11, Warszawa 1995, 61-74. 
opuściły uczelnie (lub lepiej - zostały opuszczone przez uczelnie) i przeszły do wydawnictw nieakademickich: WAM, które ciągnie cztery serie przekładów (Źródła Myśli Teologicznej i Ojcowie Żywi, oraz ewentualnie - Dzieła Jana Chryzostoma i rozpoczynające się wydawanie Apokryfów Nowego Testamentu), Opactwo Tynieckie (Źródła Monastyczne), Wydawnictwo M (Biblioteka Ojców Kościoła, Mała Biblioteka Ojców Kościoła oraz inne dzieła patrystyczne jak: Filokalia, Historia dogmatów). Powodem tego przejścia mają być ponoć względy finansowe - w co bardzo wątpię, ale wrócę do tego później. Mam poważne obawy, że ta zmiana, która wprawdzie okazała się korzystna dla serii, bo w końcu przestały zależeć od kaprysów biurokratów akademickich i mogą rozwijać się dynamicznie, wyszła jednak chyba fatalnie dla samych ośrodków akademickich KUL-u, ATK (USKW) i PAT-u, które straciły tak świetne narzędzie integracji badań naukowych, często interdyscyplinarnych oraz wizytówki dla swojej działalności naukowej. W ten sposób sprawa przekładów dzieł Ojców Kościoła stała się problemem inicjatyw indywidualnych uczonych i poszczególnych wydawnictw, a przestały się nimi interesować uczelnie. I musimy się zapytać, czy przypadkiem nie było tak od początku: czy antologie KUL-owskie nie były dziełem tylko prof. L. Małunowiczówny, a PSP ks. M. Michalskiego i grupy zapaleńców pod przewodnictwem o. E. Stanuli? Czy udział uczelni nie był tu tylko symboliczny - instytucji, które tylko dla spokoju wydawały te tomy?

Na uwagę zasługuje tu jednak pojawienie się w minionym okresie (1981 r.) pierwszego polskiego periodyku patrystycznego „Vox Patrum”, wydawanego za staraniem ks. S. Longosza przez Międzywydziałowy Zakład Badań nad Antykiem Chrześcijańskim KUL, a także opracowywany przez jednego z pracowników naukowych ATK (USKW) i dołączany (od 1978) regularnie (2 razy w roku) do „Collectanea Theologica” kilkunastostronicowy „Biuletyn Patrystyczny”. Dostarczają one możliwości (zwłaszcza pierwszy) nie tylko publikowania swoich artykułów i niewielkich przekładów, ale poprzez umieszczane $\mathrm{w}$ nich recenzje, sprawozdania, bibliografie i informacje wzajemne informowanie się o krajowym i zagranicznym życiu patrystycznym.

Przejdźmy do problemu polskiej kadry. W latach sześćdziesiątych, kiedy wstępowałem w patrystyczne szranki, nie było ani jednego pracownika habilitowanego $z$ dziedziny patrologii; ks. M. Michalski był apologetą, a p. L. Małunowicz - filologiem klasycznym. Dziś, po ćwierćwieczu, mamy już kilkunastu pracowników habilitowanych $\mathrm{w}$ dziedzinie patrologii i literatury wczesnochrześcijańskiej oraz dwa mocne ośrodki z zespołami wysoko kwalifikowanych pracowników na KUL-u i na UKSW.

Ale nie to jest największym sukcesem. W latach sześćdziesiątych, wedle raportu opracowanego na zlecenie ks. kard. K. Wojtyły ${ }^{13}$, w żadnym prawie

13 Por. R. Andrzejewski, Sytuacja dydaktyczna patrologii w seminariach duchownych, RTK 26(1979) z. 4, 53-61. Wcześniej problem ten omawiano 12 II 1974 r. w rezydencji ks. kard. 
seminarium duchownym nie uczył patrolog kwalifikowany, dziś natomiast większość seminariów posiada takowych, te zaś seminaria które ich nie mają, czują się w obowiązku szukania kwalifikowanych patrologów, zaś przełożeni (biskupi i przełożeni zakonni) zaczęli wysyłać na studia z tej dziedziny swoich młodych księży; ci zaś odbywają je za granicą (głównie w Agustinianum i Salesianum w Rzymie oraz w Paryżu), lub na wspomnianych uczelniach krajowych. Młodzi doktorzy patrologii po powrocie ze studiów organizują naukowe seminaria patrologiczne i prowadzą prace dyplomowe z patrologii w swoich rodzimych instytucjach wychowawczych, o ile naturalnie, nie wsiąkną w pracę duszpasterską. Liczba tych prac, sumiennie odnotowywanych przez „Vox Patrum”, jest pokaźna, co pozwala mieć nadzieję, że rośnie trzecie pokolenie patrologów.

Są jednak i cienie. Po pierwsze, na naszych uczelniach katolickich ciągle brak jest polskiej orientalistyki patrystycznej. Brak znawców języka syryjskiego, armeńskiego, gruzińskiego, arabskiego, etiopskiego; lepiej wygląda tylko sprawa z językiem koptyjskim. I nie jest to tylko problem wykształcenia kadry, choć prawdę mówiąc, niewiele lub nic się w tej dziedzinie nie robi, a postulaty wysunięte w 1976 r. na spotkaniu pod kierunkiem prof. L. Małunowiczówny, do dziś pozostają martwą literą. Ludzie znaleźliby się, przynajmniej z kilku specjalności, ale uczelnie katolickie orientalizm chrześcijański nie interesuje, nieliczni zaś polscy fachowcy w tej dziedzinie robią często zupełnie co innego. Niestety, religioznawstwo UJ, i nie tylko, ale i inne uniwersytety, zrozumiały to, czego polskie uczelnie katolickie zrozumieć nie mogą, że nie zajedziemy daleko w studiach nad późnym antykiem bez orientalizmu chrześcijańskiego. Chciałbym tu przypomnieć, że już Sobór w Vienne (1311) zalecał uczenie języków orientalnych na Wydziałach Teologicznych w celach ekumenicznych. Niewiele tu rozwiązują ostatnio wydane dwa słowniki: Stownik Wczesnochrześcijańskiego Piśmiennictwa Wschodu przez Instytut Wydawniczy $\mathrm{PAX}^{14}$ oraz Stownik chrześcijaństwa wschodniego J. Assfalga i P. Krügera przez Wydawnictwo „Książnica”"15.

Drugim wielkim mankamentem naszych uczelni katolickich jest brak bizantynistyki, silnie związanej z patrologią, która zaczyna rozwijać się bujnie na uniwersytetach państwowych (np. w Łodzi). Jak można mówić o ekumenizmie wschodnim bez orientalizmu chrześcijańskiego i prowadzenia badań nad historią i teologią Bizancjum oraz porządnego poznania jego historii, wiedzą chyba tylko nasi teologowie ekumeniści. Postulat kształcenia bizantynistów wysuwała również grupa robocza na wspomnianym wyżej spotkaniu w 1976 roku.

K. Wojtyły w Krakowie na sympozjum Zakładu Badań nad Antykiem Chrześcijańskim KUL podczas dyskusji nt. „Sytuacja dydaktyki antyku chrześcijańskiego w seminariach duchownych”.

${ }^{14}$ Por. M. Starowieyski, Stownik Wczesnochrześcijańskiego Piśmiennictwa Wschodu. Literatury: arabska, armeńska, etiopska, gruzińska, koptyjska, syryjska, Warszawa 1999.

${ }^{15}$ Por. J. Asfalg - P. Krüger, Stownik chrześcijaństwa wschodniego, z niem. tłum. A. Bator M.M. Dziekan, Katowice 1998. 
Trzecim brakiem naszych uczelni jest słabość historii Kościoła starożytnego, która nie zdradza w Polsce prawie żadnej działalności naukowej.

Następnie - skandaliczne przeciążenie młodej kadry pracowników naukowych, o którym nie mówi się oficjalnie. Niektórzy doskonale wykształceni patrologowie często przez kilka lat po studiach pracują w katechezie lub po prostu $\mathrm{w}$ duszpasterstwie albo $\mathrm{w}$ dziedzinach nie mających nic wspólnego $\mathrm{z}$ ich wykształceniem. Taka przerwa, nawet roczna, jest katastroficzna dla pracownika naukowego, co zresztą dobitnie podkreślano w latach siedemdziesiątych, gdy toczyła się dyskusja na temat rocznej służby wojskowej dla absolwentów szkół akademickich. Państwowe ustawodawstwo akademickie przyjęło te racje, kościelne - ignoruje je zupełnie. Kiedy zaś w końcu mogą się oni zająć patrologią, są przeciążani wykładami w różnych ośrodkach, co nie pozwala im na kontynuowanie ich pracy naukowej, często świetnie rozpoczętej. Władze uczelni katolickich udają, że nic się nie dzieje, że ich pracownicy mają swoje obowiązkowe siedem godzin zamykając oczy na fakt, że ci ludzie w swoich seminariach (diecezjalnych czy zakonnych) mają czasami drugi raz tyle samo godzin, a niekiedy także funkcje administracyjne (np. prefekci, wicerektorzy, itd.). Podobne przeciążenie dotyka czasem i starszych pracowników; jeden z kolegów opowiadał mi, że jednego roku firmował aż 38 prac magisterskich.

Wreszcie - od lat prowadzone reformy ratio studiorum zaczynają się od likwidacji godzin łaciny i greki (podobnie i ta ostatnia); zostają one zastąpione naukami bardziej „użytecznymi”, jak np. psychologia. Jeśli 15 lat temu na seminarium patrologicznym w seminarium duchownym można było pracować na tekstach łacińskich, to dziś nie ma mowy. Tak seminaria duchowne $z$ wyższych zakładów naukowych przekształcają się stopniowo w wyższe uczelnie zawodowe, a nowo upieczeni patrologowie będą z nich wychodzili bez tak koniecznego instrumentu, jakim jest język łaciński.

Jeśli jednak chodzi o sytuację patrologii w naszych seminariach duchownych, to Polska jest tu w wyjątkowo szczęśliwej sytuacji, szczególnie po ostatnich zmianach programu, przesuwających patrologię na rok III i IV; w seminariach na Zachodzie bywa ona zazwyczaj wykładana przez jeden semestr. Posiadamy trzy podręczniki, choć po dyskusjach, które prowadziliśmy na ten temat przed laty, można było się w nich spodziewać metodycznego wprowadzenia do ćwiczeń z patrologii wraz z odpowiednio wybranymi i przygotowanymi tekstami. Nie brakuje na ogół tekstów do tych ćwiczeń, wymaganych przez ostatnie ratio studiorum, o ile naturalnie patrolog zdołał zmusić rektora czy bibliotekarza do ich zakupu.

Dochodzimy teraz do punktów najdelikatniejszych: do pracy naukowej i do miejsca patrologii w teologii polskiej. Niewątpliwie brak liczących się prac $\mathrm{z}$ dziedziny patrologii jest najbardziej bolesnym punktem naszej sytuacji. Te które się ukazują, to przeważnie prace habilitacyjne, ewentualnie doktorskie. Niestety de facto została zlikwidowana świetnie zapowiadająca się seria Studia 
Antiquitatis Christianae ATK, która w tej chwili ogranicza się do wydawania cienkich zeszytów zawierających akta z sympozjów. Jest to tym boleśniejsza strata, że wiem, jak dobrze została przyjęta za granicą - sam wywiozłem kilkanaście egzemplarzy tej serii za granicę - i była szansa stworzenia polskiej serii naukowej o znaczeniu europejskim. KUL natomiast przerwał wydawanie pozycji, której pierwsze dwa tomy zrobiły furorę w świecie patrologicznym na Zachodzie; chodzi o Bibliografię antyku chrześcijańskiego autorstwa J. Czerniatowicz i C. Mazura ${ }^{16}$. Niestety śmierć autora, a może i brak pieniędzy na wydanie, podejrzewam, że również brak zrozumienia i dobrej woli, przeszkodziły w dalszej realizacji tej cennej inicjatywy, choć podobno ks. S. Longosz przygotowuje do druku obszerną Polskojęzyczna bibliografię antyku chrześcijańskiego ostatniego stulecia jako swego rodzaju jej kontynuację. Zaniechanie publikowania tych pozycji przez uczelnie klasy ATK (dziś USKW) i KUL-u byłoby wielką szkodą i stanowiłoby oznakę przemiany naszych centrów akademickich, które z ośrodków uniwersyteckich stawały by się stopniowo centrami tylko sprawnego udzielania stopni akademickich, lekceważąc problem badań naukowych.

Tak oto wygląda problem polskich patrystycznych serii naukowych. Jeśli chodzi o inne publikacje, to niestety rzadko ukazują się prace, które mogłyby ewentualnie pretendować do miejsca w literaturze europejskiej, tym bardziej, że niemal wszystkie pisane są po polsku, a polonica non leguntur. Polscy patrologowie publikują zazwyczaj stosunkowo niewielkie artykuły w lokalnych rocznikach teologicznych i w „Vox Patrum”. Nie są to jednak prace liczące się w skali europejskiej, natomiast pozycje z tej dziedziny, liczące się naprawdę w nauce europejskiej, pochodzą nie ze środowiska patrologicznego: jedyny polski autor, który słusznie doczekał się wydania na Augustinianum w Rzymie zbioru swoich prac, to prof. Ewa Wipszycka, powszechnie zresztą cytowana w literaturze naukowej Zachodu. I z tego to środowiska papirologii warszawskiej i archeologii pochodzą prace powszechnie cytowane. Świetne tomy studiów serii Chrześcijaństwo u schyłku antyku ${ }^{17}$, wydawane przez to środowisko, potwierdzają jego znaczenie na polskiej scenie naukowej. Należy przyznać, że najbardziej liczącym się czasopismem polskim o tematyce wczesnochrześcijańskiej, jest, moim zdaniem, nie „Vox Patrum”, ale „Journal of Juristical Papirology", wydający nowe teksty i świetne prace polskich uczonych w językach kongresowych.

Jako środowisko patrologiczne jesteśmy potęgą europejską jedynie w dziedzinie tłumaczeń, ale za to kopciuszkami w dziedzinie pracy naukowej. I jeżeli

${ }^{16}$ Por. J. Czerniatowicz - Cz. Mazur, Recepcja antyku chrześcijańskiego w Polsce. Materiały bibliograficzne, t. I: Wiek XV-XVIII, cz. 1: Autorzy i teksty, Lublin 1978; cz. 2: Problemy doktrynalne i historia wczesnego chrześcijaństwa, Lublin 1983.

17 Por. Chrześcijaństwo u schyłku starożytności. Studia źródłoznawcze, pod red. T. Derdy E. Wipszyckiej, t. 1, Warszawa 1997; t. 2, Kraków 1999. 
należy się ogromna wdzięczność ks. S. Longoszowi za stworzenie i redagowanie pisma „Vox Patrum”, i jeżeli cieszymy się bardzo z jego sukcesów, oraz w pełni doceniamy wkład Zakładu Antyku Chrześcijańskiego KUL w jego wydawanie, to niemniej pozwalam sobie wyrazić nieśmiałą sugestię, aby Redakcja dokonywała surowszej selekcji prac publikowanych, ponieważ obok bardzo dobrych artykułów pojawiają się też teksty mierne i niestety takie, które nigdy nie powinny ukazać się drukiem; ponadto kuracja odchudzająca wyszłaby pismu na korzyść. A może wydać rocznie jeden numer po polsku i jeden w językach kongresowych? Z innych uwag wydawniczych, to spostrzeżenie, że brak w naszych periodykach recenzji polskich prac naukowych.

Polscy patrologowie uczestniczą tylko w niewielkim stopniu w międzynarodowym życiu naukowym: z rzadka publikują w obcych językach i czasopismach, podobnie jak polskie książki wydane w językach kongresowych należą do rzadkości; $z$ rzadka też biorą udział w wielkich spotkaniach międzynarodowych, jak np. w międzynarodowych kongresach patrystycznych w Oksfordzie, gdzie co cztery lata dokonuje się przegląd światowej patrologii. Ta postawa na ogół kontrastuje ze stosunkowo dużą liczbą pracowników habilitowanych.

Nie chcę tu wysuwać kolejnych zarzutów pod adresem naszego środowiska. Wierzę, że wszyscy robią tyle, ile mogą. Głęboko wadliwy jest system nauki katolickiej w Polsce, podobnie jak głęboko chore są polskie wyższe uczelnie, które zajmują się wszystkim, tylko nie jednym z podstawowych zadań uczelni wyższych - pracą naukową, co niewątpliwie rzutuje na poziom teologii w Polsce.

Jeżeli problem pracy naukowej jest bardzo delikatny, to jeszcze delikatniejszą sprawą jest miejsce patrologii w polskiej teologii. Zacznijmy od truizmu: patrologia jest nauką teologiczną, podczas gdy zarówno ATK (UKSW) jak i KUL usunęły praktycznie patrologię z Wydziałów Teologicznych: na KUL-u istnieje ona wprawdzie teoretycznie na Wydziale Teologicznym, ale w Instytucie Historycznym (ze wszystkimi tego konsekwencjami), natomiast na UKSW istnieje na Wydziale Nauk Społecznych i Historycznych. Powodów tego dziwnego wydarzenia nigdy nie zrozumiałem. Jest to curiosum w skali światowej, gdzie każdy jako tako szanujący się Wydział Teologiczny ma patrologię. Sam nie czuję się teologiem i może czegoś tu nie rozumiem, ale nie jestem w stanie pojąć, jak po ponad stu latach wielkich studiów europejskich nad teologią patrystyczną, ktoś mógł wpaść na taki pomysł, i co gorzej, że uznano to powszechnie za sytuację normalną. A skutki tego ponosi polska teologia.

Najpierw studenci patrologii muszą się uczyć poglądów Lutra, Oświecenia i innych tematów historycznych zupełnie im nie potrzebnych, marnują czas na rzeczy zbyteczne, stąd braki $\mathrm{w}$ ich podstawowym wykształceniu. $\mathrm{Z}$ kolei nieobecność patrologii wśród dyscyplin teologicznych spowodowała, że polscy 
teologowie różnych specjalności - oczywiście z kilkoma bardzo zresztą rzadkimi chwalebnymi wyjątkami - ani nie rozumieją ani nie czują teologii Ojców ani też historycznego wymiaru teologii, i w tej sytuacji nie tylko zabierają głos, ale prowadzą prace doktorskie z nauki Ojców, które recenzują często nie patrologowie. Co z tego wychodzi, można sobie wyobrazić. Proszę mnie zwolnić od podawania przykładów. Argument patrystyczny w teologii jest najczęściej formułowany „metodą enchiridionu”: kilka cytacików opartych na polskich przekładach (nie zawsze zresztą najlepszych) lub na wydaniach tekstów, nie zawsze pierwszej jakości; prace dyplomowe wykazują często brak wiedzy, metody, narzędzi i metody. Teologia musi stać na dwóch nogach: Biblii i Tradycji, polska zaś zdaje się stoi nieźle (choć nie znam się na tym) na Biblii, drugą natomiast jej amputowano i nawet nie dano szczudeł. Oto skutki wyeliminowania patrologii z Wydziałów Teologicznych. Czy to ignorowanie teologii patrystycznej, na której wychowywali się wszyscy wielcy teologowie współcześni, nie jest powodem jałowości polskiej teologii?

Pozostaje jeszcze jeden problem, który trzeba omówić, mianowicie ciągle powtarzający się argument braków finansowych. Jest on z gruntu dziwny. Wiemy dobrze, że stan finansowy wszystkich szkół wyższych jest nienajlepszy. Ale po pierwsze: mówię tu szczególnie o Wydawnictwie ATK (obecnie UKSW), bo nie wiem, jak wygląda sprawa na KUL-u, winne są same wydawnictwa, które nic nie robią, by sprzedać i promować swoje książki, które poszukiwane w innych miastach - zalegają magazyny Wydawnictwa. Po drugie - jak to się dzieje, że wtedy, gdy KUL i ATK zawieszają jedno po drugim swoje wydawnictwa patrystyczne, Uniwersytet Łódzki rozpoczyna serię Byzantina Lodziensia, Uniwersytet Jagielloński Byzantina et Slavica Cracoviensia, a Uniwersytet Warszawski Chrześcijaństwo u schytku starożytności. Na pewno, nie dzieje się to bez trudności. Ale oni chcą i rozumieją potrzebę serii naukowych w łonie uczelni. Wyspiański pisał: „Wy nie chcecie nawet chcieć".

Jak ogólnie wygląda sytuacja? Do minusów już powracać nie będę. Niewątpliwie o wiele lepiej niż wtedy, gdy w latach sześćdziesiątych moje pokolenie kończyło swoje studia z patrologii. Istnieją książki - dzieła Ojców po polsku, w każdym razie większość ważnych pozycji, istnieje szeroka rzesza wiernych czytelników - najczęściej świeckich, istnieje patrologia dobrze i solidnie ulokowana w seminariach, istnieją wydawnictwa, które chcą wydawać pisma Ojców Kościoła, które podzieliły między sobą rynek wydawniczy, a książki o Ojcach na ogół się rozchodzą, istnieje czasopismo patrystyczne, w którym można publikować prace $\mathrm{z}$ tej dziedziny, ukazuje się sporo prac, ważniejszych czy mniej ważnych z dziedziny patrologii, istnieją w końcu dwa ważne centra patrologiczne na wyższych uczelniach katolickich. Nasze pokolenie, już weteranów, zbiera się do odejścia na emerytury. Jesteśmy świadomi swoich dokonań, ale także świadomi i tego, czego nie zdołaliśmy uczynić. Próbą 
podsumowania dorobku i braków był niniejszy referat, który nie rości sobie bynajmniej prawa do podania doskonałej syntezy, a którego autor jest świadom, że wiele tez może wywołać kontrowersje czy opór, ufam, że nie obrazę. Ufamy, że to, czego my nie zrobiliśmy, zrobi pokolenie młodszych i najmłodszych patrologów, które wchodzi w szranki naukowe.

\title{
QUELQUES REMARQUES SUR LA SITUATION DE LA PATROLOGIE EN POLOGNE
}

\author{
(Résumé)
}

Cet article décrit la situation de la patrologie en Pologne en soulignant, entre autres, particulier le problème des traductions des Pères grecs et latins, des études patristiques et des publications. Les thèses principales de l'article ont été présentés par l'auter dans l'article paru dans le livre Théologie en Pologne - aujourd'hui, dir. Henri Bourgeois, Paris 1998, 74-79. 